\title{
Meningkatkan Kemampuan Menggambar Berdasarkan Contoh dengan Metode Penugasan pada Anak Kelompok B di Taman Kanak-Kanak Syaloom Ende
}

\begin{tabular}{|c|c|}
\hline & $\begin{array}{c}\text { Lebe Wele }^{\mathbf{1}^{*}} \text {, Marta Kala } \\
\text { 1,2 TKK Syaloom Ende } \\
\text { Jalan Marilonga, Ende Tengah,Kab. Ende, Nusa Tenggara Timur } \\
{ }^{*} \text { Corresponding Author }: \underline{\text { lebewele1@ @mail.com }}\end{array}$ \\
\hline Info Artikel & Abstract \\
\hline $\begin{array}{l}\text { Sejarah Artikel: } \\
\text { Diterima: } 27 / 01 / 2020 \\
\text { Direvisi: } 19 / 03 / 2020 \\
\text { Disetujui: } 25 / 03 / 2020 \\
\\
\text { Keywords: } \\
\text { Assignment } \\
\text { Dethod, } \\
\text { Drawing } \quad \text { Skills }\end{array}$ & $\begin{array}{l}\text { This study aims to uncover and describe: (1) Implementation of method of assignment in } \\
\text { learning to draw in group B children in TKK Syalom, Ende, (2) The ability to draw } \\
\text { children in group B in TKK Syalom after the assignment method is applied. This research } \\
\text { is a class action research (CAR) implemented in } 2 \text { cycles. The data collection techniques } \\
\text { used are observation and documentation. The subjects of this research were } 19 \text { children in } \\
\text { group B. The results showed that; (1) The assignment learning method has been applied } \\
\text { well in drawing learning for group B children in TTK Syaloom Ende. The observation } \\
\text { results proved that in cycle I the implementation rate was 75\% with good category and in } \\
\text { cycle II increased to be very good with percentage of } 90 \% \text {, (2) The ability to draw children } \\
\text { increased after the assignment method was applied to group B children in TKK Syaloom. } \\
\text { This can be seen from the observation results on the pre-cycle, for the newly developed } \\
\text { children, there were } 6 \text { children, children who start to grow, there were } 10 \text { children, } \\
\text { children develop according to expectations were } 3 \text { children and for children who grow } \\
\text { very well is no one. In the I cycle, of } 19 \text { peoples, for a newly developed child is no one, } \\
\text { children who start developing were } 9 \text { peoples, children who thrive as expected were } 8 \\
\text { children and grow very well were } 2 \text { children. In cycle II increased from } 19 \text { children, to the } \\
\text { newly developed no one, for which began to grow there was also no one, for children who } \\
\text { grew very well were } 7 \text { children and grew as expected were } 12 \text { people. Based on these } \\
\text { results it can be concluded that the use of assignment methods can improve drawing skills. }\end{array}$ \\
\hline
\end{tabular}

Abstrak

Penelitian ini bertujuan untuk mengungkap dan mendeskripsikan;(1) Penerapan metode penugasan dalam pembelajaran menggambar pada anak kelompok B di TKK Syalom, Ende, (2) Kemampuan menggambar pada anak di kelompok B TKK Syalom setelah diterapkan metode penugasan. Penelitian ini adalah penelitian tindakan kelas (PTK) yang dilaksanakan dalam 2 siklus. Teknik pengumpulan data yang digunakan adalah Observasi dan dokumentasi. Subjek penelitian ini adalah anak kelompok B berjumlah 19 orang. Hasil penelitian menunjukan bahwa; (1) Metode pembelajaran penugasan sudah diterapkan dengan baik dalam pembelajaran menggambar pada anak kelompok B di TTK Syaloom Ende. Hasil observasi membuktikan bahwa pada siklus I tingkat penerapan adalah $75 \%$ dengan kategori baik dan pada siklus II meningkat menjadi sangat baik dengan persentase $90 \%$, (2) Kemampuan menggambar anak meningkat setelah diterapkan metode penugasan pada anak kelompok B di TKK Syaloom. Hal ini dapat dilihat dari hasil observasi pada Pra siklus, untuk anak yang baru berkembang (BB) adalah 6 orang anak, anak yang mulai berkembang (MB) adalah 10 orang anak, anak berkembang sesuai harapan (BSH) adalah 3 orang anak dan untuk anak bertumbuh sangat baik (BSB) 0 anak. Pada siklus I dari 19 orang anak baru berkembang 0 orang, mulai berkembang 9 orang, berkembang sesuai harapan adalah 8 orang anak dan bertumbuh sangat baik adalah 2 orang anak. Pada siklus II meningkat dari 19 anak yang baru berkembang 0 orang, mulai berkembang 0 orang, bertumbuh sangat baik adalah 7 orang anak, dan untuk yang berkembang sesuai harapan berjumlah 12 orang. Berdasarkan hasil tersebut dapat disimpulkan bahwa penggunaan metode penugasan dapat meningkatkan kemampuan menggambar.

"Alamat korespondensi:

TKK Syaloom Ende

Jalan Marilonga, Ende Tengah ,Kab. Ende, NTT

E-mail: lebewele1@gmail.com
() 2020 Program Studi PGSD Universitas Flores Email: primagistrauniflor@gmail.com 


\section{PENDAHULUAN}

Perhatian akan pendidikan usia dini mendapat dukungan prioritas dari pemerintah. Hal ini terbukti dari bentuk dukungan dana dan perhatian kesejahteraan tenaga pendidik. Keberhasilan pendidikan anak tetap menjadi tanggung jawab bersama antara pemerintah, orangtua dan guru. Walaupun demikian peran guru menduduki posisi sentral, karena tanpa guru segala proses pembentukan potensi anak tidak dapat dilaksanakan secara baik.

Guru sebagai pendidik pertama bagi anak prasekolah dituntut untuk berperan membentuk dan mengembangkan seluruh bakat, potensi pengetahuan anak prasekolah sehingga mampu mengembangkan imajinasi dalam bentuk gambar-gambar karena mereka belum mampu menulis dan membaca.

Anak usia Prasekolah dengan berbagai perilaku biasanya menarik perhatian orang Dewasa. Perkembangan berpikir anak usia Prasekolah juga sangat pesat. Perkembangan intelektual anak terjadi pada usia nol sampai pada usia prasekolah. Pada usia tersebut segala potensi kemampuan anak dapat dikembangkan secara optimal yang didukung oleh orangorang dewasa yang berada disekitar anak termasuk guru.

Salah satu materi yang perlu diperhatikan dalam kemampuan berpikir anak adalah tentang kemampuan menggambar berdasarkan contoh. Materi ini berkaitan erat dengan daya pikir dan daya tangkap anak serta keterampilan menuangkan kembali apa yang dilihat lewat menggambar berdasarkan contoh yang diperlihatkan guru. Materi ini juga berkaitan dengan kemampuan anak mengolah pikiran, sehingga segala yang dilihatnya merangsang panca indranya untuk merespon obyek tersebut dan dapat menuangkan kembali lewat menggambar bebas sesuai dengan tujuan pembejaran yang diharapkan dapat dicapai anak setelah pembelajaran.

Berdasarkan hasil observasi yang dilakukan dikelas, guru menemukan permasalahan, dimana anak belum mampu menggambar bebas menurut pikiran dan imajinasinya sendiri. Masalah ini ditandai dengan anak tidak mampu menggambar bebas secara klasikal $70 \%$. Kemampuan menggambar anak berdasarkan contoh-contoh yang diberikan guru sebesar $25 \%$, dan anak yang hanya mencoret-co9ret saja sebesar 5 $\%$.

Fakta empirik inilah menuntut peran guru untuk melakukan refleksi untuk menemukan akar permasalahan yang tepat sebagai upaya untuk meningkatkan kemampuan anak dalam menuangkan apa yang pernah dilihtnya lewat menggambar. Hasil refleksi ditemukan bahwa sebagian besar anak kurang perhatian pada saat guru memperlihatkan contoh gambar, anak terlihat sibuk bermain dengan sesama teman dibarisan belakang. Hal lain yang juga membuat anak kurang perhatian yaitu dikarenakan ratio guru dan anak tidak seimbang, jumlah murid melebihi daya tampung yang seharusnya 1 berbanding 15 namun realitanya 1 berbanding 20 sehingga guru mengalami kesulitan dalam mengealola kelas besar yang membuat anak tidak ada perhatian terhadap gambar yang diperlihatkan atau dicontohkan guru.

Oleh karena itu maka bersama supervaisor dan guru menemukan akar dari permasalahan tersebut yaitu guru belum menggunakan metode pembelajaran yang tepat dimana metode tersebut mampu mengajak anak tenang, fokus melihat contoh gambar dan mendengar penjelasan guru tentang bagaimana cara menggambar sesuai dengan contoh yang sudah dilihat.

Berdasarkan permasalahan di atas, maka peneliti tergugah untuk memperbaiki pembelajaran dan judul penelitian: Meningkatkan Kemampuan Menggambar Berdasarkan Contoh Melalui Metode Penugasan Pada Anak Kelompok B di Taman Kanak - Kanak Syaloom Ende.

\section{METODE PENELITIAN}

Penelitian ini termasuk jenis penelitian tindakan kelas (PTK) yang dilksanakan dalam 2 siklus. Teknik pengumpulan data yang digunakan adalah (1) Observasi, (2) dokumentasi. Subjek penelitian ini adalah anak kelompok B berjumlah 19 orang. Teknik analisis data yang digunakan menggunakan model oleh Kemmis \& McTaggart, dalam (Arikunto,2010). 


\section{HASIL DAN PEMBAHASAN}

\section{A. Hasil Penelitian}

\section{Deskripsi Awal Proses Pembelajaran Bercerita pada Anak Kelas B di TKK Syaloom Tahun Pelajaran 2017/2018}

Penelitian ini dilaksanakan di Kelas B TKK Syaloom di Ende. Jumlah anak 19 orang. Penelitian ini dilakukan pada bulan Sepetember 2018 yang terdiri dari dua siklus. Siklus pertama terdiri dari satu kali pertemuan dengan materi menggambar dan siklus II terdiri dari satu kali pertemuan dengan materi yang sama.

Setiap kegiatan pembelajaran dilaksanakan dengan menggunakan metode penugasan sesuai dengan RPPH. Selanjutnya untuk melihat perkembangan anak setelah penerapan metode penugasan dengan materi menggambar guru memberikan penilaian untuk mengetahui kemampuaan memnggambar anak. Berikut ini akan disajikan data hasil ganbar anak kelompok B pada kegiatan pra siklus sbb:

\section{Tabel 1}

Hasil Penilaian Gambar Pra Siklus Anak Kelompok B TKK Syalom

\begin{tabular}{|c|c|c|c|c|c|}
\hline \multirow[t]{2}{*}{ No } & \multirow[t]{2}{*}{ Nama anak } & \multicolumn{4}{|c|}{ Nilai } \\
\hline & & $\mathrm{BB}$ & MB & $\mathrm{BSH}$ & BSB \\
\hline 1 & Josima & & $* * 2$ & & \\
\hline 2 & Lia & & $* * 2$ & & \\
\hline 3 & Givon & & $* * 2$ & & \\
\hline 4 & Vano & & & $* * * 3$ & \\
\hline 5 & Miki & $* 1$ & & & \\
\hline 6 & Eci & & $* * 2$ & & \\
\hline 7 & Eyo & $* 1$ & & & \\
\hline 8 & Julio & & $* * 2$ & & \\
\hline 9 & Laura & & $* * 2$ & & \\
\hline 10 & Marcelino & $* 1$ & & & \\
\hline 11 & Flora & $* 1$ & & & \\
\hline 12 & Olir & & $* * 2$ & & \\
\hline 13 & Cena & & & $* * * 3$ & \\
\hline 14 & Clarisa & $* 1$ & & & \\
\hline 15 & Kevin & & $* * 2$ & & \\
\hline 16 & Pipin & & $* * 2$ & & \\
\hline 17 & Selena & & & $* * * 3$ & \\
\hline 18 & Adytia & $* 1$ & & & \\
\hline \multirow[t]{2}{*}{19} & Nadila & & $* * 2$ & & \\
\hline & Jumlah & 6 & 10 & 3 & \\
\hline $\begin{array}{l}\text { Ket: } \\
\text { berk } \\
\text { Har: }\end{array}$ & $\begin{array}{l}\text { BB: (Belum } \\
\text { bang**2), } \\
\text { n***3) BSB }\end{array}$ & $\begin{array}{l}\text { Berke } \\
\text { BSH } \\
\text { erkemb }\end{array}$ & $\begin{array}{l}\text { ang } \\
\text { (Berk } \\
\text { g san }\end{array}$ & $\begin{array}{l}\text { MI } \\
\text { lbang } \\
\text { baik* }\end{array}$ & $\begin{array}{l}\text { (mulai } \\
\text { sesuai } \\
\text { 4) }\end{array}$ \\
\hline
\end{tabular}

Berdasarkan data pra siklus di atas dapat diketahui bahwa perkembangan anak kelompok B dalam menggambar bebas adalah belum berkembang atau $* 1$ sebanyak 6 orang atau $31.57 \%$, Mulai berkembang 10 orang atau \% dan Baru sesuai harapan 3 orang atau $15.78 \%$ serta berkembang sangat baik 0 anak. Berdasarkan data di atas maka refkelsi peneliti adalah meningkatkan kemampuan anak dengan cara memberikan tugas menggambar bebas. Selanjutnya data pra siklus itu dapat digambar dalam bentuk diagram sbb:

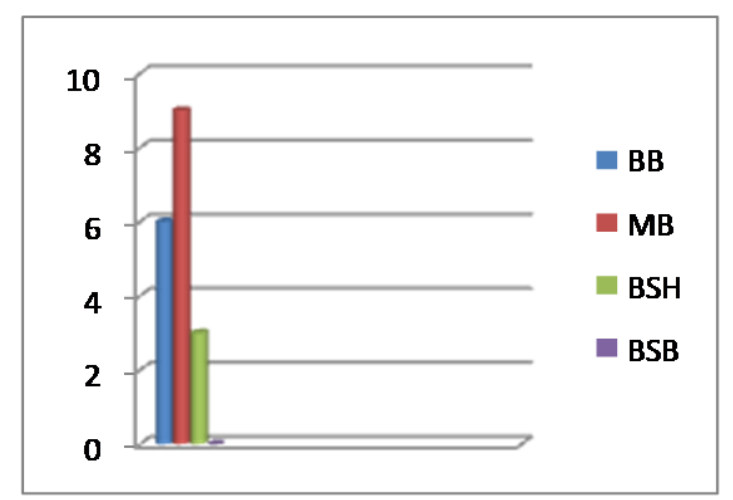

Gambar 1. Diagram Kemampuan menggambar anak kelompok B di TKK Syalom

\section{Deskripsi Hasil Tindakan Siklus I}

Tahap ini peneliti menyiapkan RPPH. Selain itu, peneliti membuat Lembar Kerja Siswa dan lembar pengamatan yang akan digunakan pada saat pembelajaran. Yang dilaksanakan dalam tindakan ini adalah refleksi awal, mengindentifikasi permasalahan, merumuskan permasalah secara operasional yang relevan, merumuskan hipotesis tindakan yang bersifat tentatif yang memungkinkan anak mengalami perubahan dan menetapkan serta merumuskan tindakan.

\section{a. Perencanaan}

Pada tahap ini penulis mempersiapkan $\mathrm{RPPH}$, dan lembar kerja siswa berupa gambar. Alat-alat gambar seperti kertas, pencil, krayon, penghapus.

b. Tindakan

Tindakan yang dilakukan adalah menerapkan Langkah-langkah modote pembelajaran penugasan:

1. Guru Menjelaskan gambar kepada anak.

2. Guru membagikan gambar kepada anak.

3. Guru membagi pelaralatan mengambar. 
4. Guru membimbing anak saat mengambar.

5. Guru Mengecek hasil gambar dan memeriksa pekerjaan. Jika waktu pengerjaan soal sudah selesai, anak wajib mengumpulkan lembar jawaban.

c. Observasi

Observasi dilakukan untuk mengetahui penerapan model penugasan dalam pembelajaran menggambar anak kelompok B. Hasil observasi dari observer dapat disajikan pada tabel di bawah ini.

Tabel 2

Aktifitas Guru dalam Menerapkan Metode Penugasan Pada Siklus I

\begin{tabular}{lc} 
Pada Siklus I & Skor \\
\hline \multicolumn{3}{c}{ Aspek Yang Diobservasi } & \\
\hline Tugas yang diberikan harus jelas & 3 \\
Tempat dan lama waktu penyelesaian & 3 \\
tugas harus jelas & 3 \\
Tugas yang diberikan terlebih dahulu & 3 \\
dijelaskan/diberikan petunjuk yang jelas, \\
agar siswa yang belum mampu memahami \\
tugas itu berupaya untuk menyelesaikannya \\
Memberi dorongan terutama bagi siswa \\
yang lambat atau kurang bergairah \\
mengerjakan tugas
\end{tabular}

Guru harus memberikan bimbingan utamanya kepada siswa yang mengalami kesulitan belajar atau salah arah dalam mengerjakan tugas

\begin{tabular}{lc}
\hline Jumlah & 15 \\
\hline Prosentase & 75 \\
\hline Kategori & Baik
\end{tabular}

Ket: Ket: SB: Sangat Baik (4),B : Baik (3), C: Cukup (2),K: Kurang (1)

Berdasarkan data hasil observasi pada tabel di atas dapat disimpulkan bahwa penerapan metode penugasan dalam menggambar anak kelompok B pada TKK Syaloom tergolong baik atau sebesar $75 \%$. Selanjutnya dapat dilihat pada diagram 4.2 sebagai berikut:

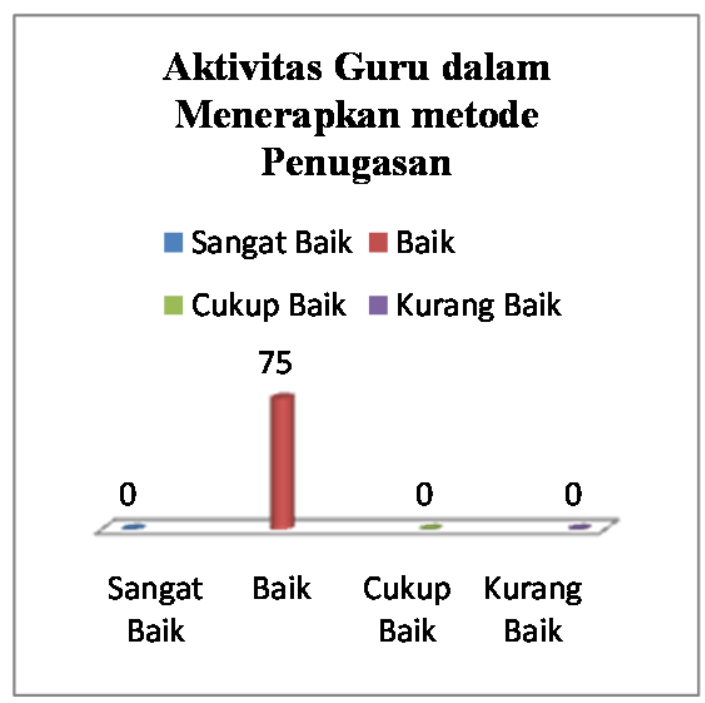

Gambar 2. Diagram Aktivitas Guru dalam menerapkan metode penugasan

d. Evaluasi

Berdasarkan hasil evaluasi yang dilakukan untuk mengetsahui kemampuan anak dalam menggambar maka berikut ini disajikan pada Tabel 3 dibawah ini.

Tabel 3

Hasil Penilaian Gambar Siklus I Anak Kelompok B TKK

\begin{tabular}{|c|c|c|c|c|c|}
\hline \multicolumn{6}{|c|}{$\begin{array}{ll}\text { Syalom } \\
\end{array}$} \\
\hline \multirow{2}{*}{ No } & \multirow[t]{2}{*}{ Nama anak } & \multicolumn{4}{|c|}{ Nilai } \\
\hline & & BB & MB & BSH & BSB \\
\hline 1 & Josima & $* 1$ & & & \\
\hline 2 & Lia & & $* * 2$ & & \\
\hline 3 & Givon & & $* * 2$ & & \\
\hline 4 & Vano & & & $* * * 3$ & \\
\hline 5 & Miki & $* 1$ & & & \\
\hline 6 & Eci & & $* * 2$ & & \\
\hline 7 & Eyo & $* 1$ & & & \\
\hline 8 & Julio & & $* * 2$ & & \\
\hline 9 & Laura & & $* * 2$ & & \\
\hline 10 & Marcelino & $* 1$ & & & \\
\hline 11 & Flora & $* 1$ & & & \\
\hline 12 & Olir & & $* * 2$ & & \\
\hline 13 & Cena & & & $* * * 3$ & \\
\hline 14 & Clarisa & $* 1$ & & & \\
\hline 15 & Kevin & & $* * 2$ & & \\
\hline 16 & Pipin & & $* * 2$ & & \\
\hline 17 & Selena & $* 1$ & & & \\
\hline 18 & Adytia & $* 1$ & & & \\
\hline 19 & Nadila & $* 1$ & & & \\
\hline & Jumlah & 9 & 8 & 2 & \\
\hline
\end{tabular}

Ket: BB: (Belum Berkembang *1) MB (mulai berkembang**2) BSH (Berkembang sesuai Harapan***3) BSB (Berkembang sangat baik $* * * * 4)$

Beradsarkan data di atas dapat diketahui bahwa perkembangan anak kelompok B dalam menggambar bebas adalah belum berkembang atau $* 1$ sebanyak 9 orang atau 47,36\%, Mulai 
berkembang 8 orang atau $42,11 \%$ dan Baru sesuai harapan 2 orang atau $10.53 \%$ serta berkembang sangat baik 0 anak. Berdasarkan data di atas maka refkelsi peneliti adalah meningkatkan kemampuan anak dengan cara memberikan tugas menggambar bebas. Selanjutnya data itu dapat digambar dalam bentuk diagram sbb:

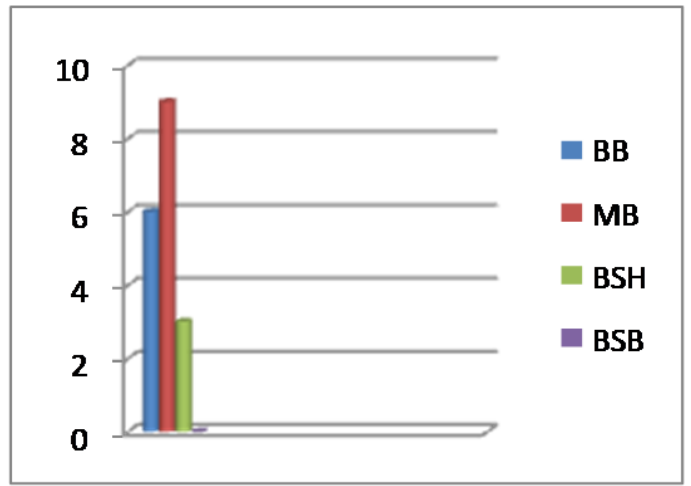

Gambar 3. Diagram Kemampuan Menggambar Anak Kelompok B di TKK Syalom Siklus I

\section{e. Refleksi}

Refleksi pada siklus I mengungkapkan bahwa ada beberapa hal yang menghambat dalam meningkatkan kemampuan menggambar anak adalah:

1. Anak kurang memahami digambar.

2. Anak kurang memahami penjelasan gambar

3. Anak tidak memperhatikan penjelasan tentang menggamabar dari guru.

Berdasarkan hasil reflekasi itu, peneliti akan memperbaiki strategi yang akan digunakan dalam siklus II.

\section{b. Deskripsi Hasil Pelaksanaan Tindakan Siklus II}

Seperti sebelumnya peneliti menyiapkan RPPH, peneliti membuat Lembar Kerja Siswa berupa gambar yang akan digunakan pada saat pembelajaran.

\section{a. Perencanaan}

Kegiatan perencanaan yang dilakukan pada siklus II sama seperti pada siklus I dengan materi yang sama. Pada tahap siklus II ini, dilakukan untuk memperbaiki kekurangan pada siklus 1 yang belum teratasi. Pada tahap ini penulis mempersiapkan RPPH, dan lembar kerja siswa berupa gambar. Alat-alat gambar seperti kertas, pencil, krayon, penghapus.

b. Tindakan

1. Kegiatan Awal

a. Doa

b. Mengecek kehadiran anak

c. Guru menyiapkan peserta didik secara psikis dan fisik untuk mengikuti proses pembelajaran.

d. Apersepsi sebagai pengggalian pengetahuan awal siswa terhadap materi yang akan diajarkan.

e. Guru menyampaikan tujuan pembelajaran dan pokok-pokok materi yang akan dipelajari.

f. Penjelasan tentang cara mengambar.

2. Kegiatan Inti

a. anak menggambar sesuai petunjuk guru.

b. Guru mengawasi dan membantu anak yang belum mampu menggambar dengan baik

c. Guru melakukan penilaian proses menggmabar anak.

d. Guru mengadakan refleksi dengan bertanya kepada anak tentang halhal yang dirasakan belum dipahami dengan baik.

c. Kegiatan akhir

a. Guru memberikaan kesimpulan terhadap hasil gambar anak

b. Guru memberikan tugas latihan menggambar di rumah.

c. Observasi

Tahap pengamatan (observasi) ini meliputi aktivitas guru dan aktivitas anak yang dilaksanakan pada saat tahap pelaksanaan tindakan sedang berlangsung, (keduanya berlangsung pada waktu yang sama). Melakukan observasi sesuai dengan format yang sudah di siapkan dan mencatat semua hal-hal yang diperlukan yang terjadi selama pelaksanaan tindakan berlangsung. Hasil penilaian aktivitas guru dapat dilihat pada tabel berikut ini. 
PRIMA MAGISTRA: Jurnal Ilmiah Kependidikan Nomor 1, Volume 1, April 2020, hal 125-132

Tabel 4

Aktifitas Guru Dalam Menerapkan Metode Penugasan Siklus II

\begin{tabular}{cc}
\hline Aspek Yang Diobservasi & Skor \\
\hline Tugas yang diberikan harus jelas & 4
\end{tabular}

Tempat dan lama waktu penyelesaian tugas harus jelas

Tugas yang diberikan terlebih dahulu dijelaskan/diberikan petunjuk yang jelas, agar siswa yang belum mampu memahami tugas itu berupaya untuk menyelesaikannya

Memberi dorongan terutama bagi siswa yang lambat atau kurang bergairah mengerjakan tugas

Guru harus memberikan bimbingan utamanya kepada siswa yang mengalami kesulitan belajar atau salah arah dalam mengerjakan tugas

Jumlah 18

\begin{tabular}{ll}
\hline Prosentasi & 90
\end{tabular}

Kategori $\quad$ Sangat Baik

Ket: Ket: SB: Sangat Baik (4),B : Baik (3), C: Cukup (2),K: Kurang (1)

Berdasarkan data hasil observasi pada tabel di atas dapat disimpulkan bahwa penerapan metode penugasan dalam menggambar anak kelompok B pada TKK Syaloom tergolong sangat baik atau sebesar 90 $\%$. Selanjutnya dapat dilihat pada diagram berikut:

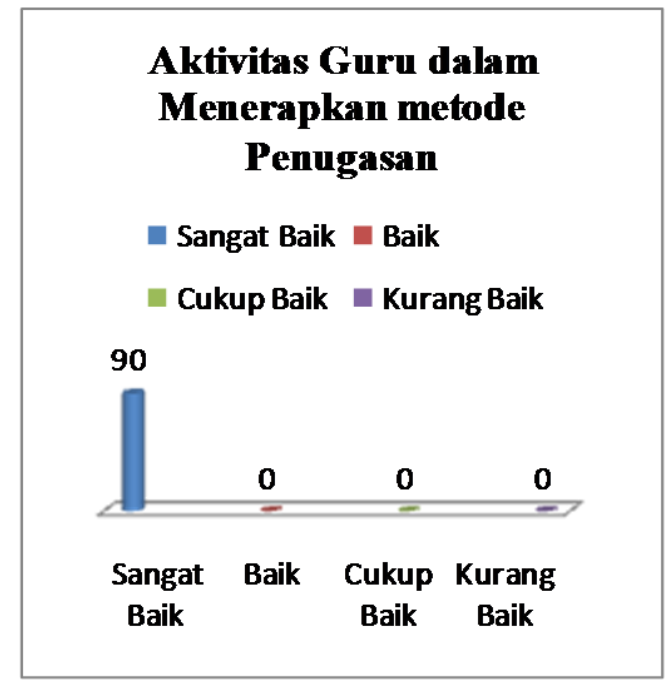

Gambar 4 Diagram Aktivitas Guru dalam Menerapkan Metode Penugasan.

\section{d. Evaluasi}

Untuk mengetahui hasil mengambar anak maka berikut ini akan disajikan hasil observasi aktifitas anak dalam menggambar sbb:

Tabel 5

Hasil Menggambar Anak Kelompk B Di TKK Syaloom Ende

\begin{tabular}{|c|c|c|c|c|}
\hline \multirow[t]{2}{*}{ No } & \multirow[t]{2}{*}{ Nama anak } & \multicolumn{3}{|c|}{$\begin{array}{c}\text { Nilai } \\
\end{array}$} \\
\hline & & BB & MB & BSH BSB \\
\hline 1 & Josima & & $* * 2$ & \\
\hline 2 & Lia & & & $* * * 3$ \\
\hline 3 & Givon & & & $* * * 3$ \\
\hline 4 & Vano & & & $* * * 3$ \\
\hline 5 & Miki & & $* * 2$ & \\
\hline 6 & Eci & & & $* * * 3$ \\
\hline 7 & Eyo & & $* * 2$ & \\
\hline 8 & Julio & & & $* * * 3$ \\
\hline 9 & Laura & & & $* * * 3$ \\
\hline 10 & Marcelino & & $* * 2$ & \\
\hline 11 & Flora & & & $* * * 3$ \\
\hline 12 & Olir & & & $* * * 3$ \\
\hline 13 & Cena & & & $* * * 3$ \\
\hline 14 & Clarisa & & $* * 2$ & \\
\hline 15 & Kevin & & & $* * * 3$ \\
\hline 16 & Pipin & & & $* * * 3$ \\
\hline 17 & Selena & & & $* * * 3$ \\
\hline 18 & Adytia & & $* * 2$ & \\
\hline 19 & Nadila & & $* * 2$ & \\
\hline & Jumlah & 0 & 7 & 12 \\
\hline
\end{tabular}

Beradsarkan data di atas dapat diketahui bahwa perkembangan anak kelompok B dalam menggambar bebas adalah brelum berkembang atau $* * 2$ sebanyak 0 orang atau $0 \%$, Mulai berkembang 7 orang atau $36,84 \%$ dan Baru sesuai harapan 12 orang atau $63,16 \%$ serta berkembang sangat baik 0 anak. Berdasarkan data di atas maka refkelsi peneliti adalah menhentikan sikulus ke dua karena berdasarkan kriteria yang ditetapkan $75 \%$ anak sudah mampu menggmabar.. Selanjutnya data itu dapat digambar dalam bentuk diagram sbb: 


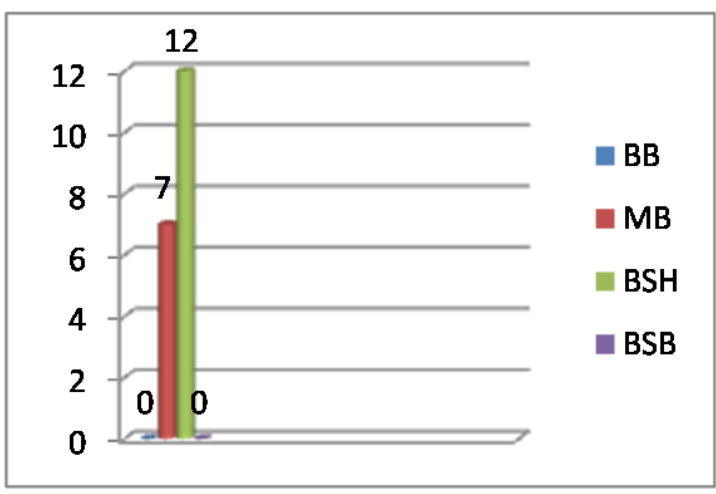

Gambar 5 Diagram Kemampuan Menggambar Anak Kelompok B Di TKK Syalom Siklus II

e. Refleksi

Refleksi pada siklus II Mengungkapkan bahwa telah terjadi peningkatan kemampuan menggambar anak:

1. Anak mampu mengambar sesuai petunjuk yang disampaikan guru.

2. Anak mampu mewarnai sesuai gambar aslinya.

\section{B. Pembahasan}

1. Penerapan Metode Penugasan pada anak kelompok B di TKK Syaloom Ende

Metode pembelajaran penugasan adalah salah satu cara yang digunakan guru dalam menyampaikan materi pembelajaean. Materi yang menggunakan metode ini adalah menggambar. Metode ini sangat cocok karena karakteruistik materi yang hendak diajakrkan adalah berkaitan dengan portofolio anak, atau karya anak. Metode ini digunakan dengan tujuan untuk mengembangkan potensi dan bakat anak dalam menyalurkan karya seni dalam bentuk gambar.

Berdasarkan data hasil obervasi penerapan metode pembelajaran penugasan pada siklus I sebesar $95 \%$ atau kategori baik dan pada siklus II meningkat menjadi $90 \%$ atau kategori sangat baik.

Berdasarkan data hasil observer tersebut maka dapat disimpulkan bahwa guru sudah mampu menerapkan metode penugasan secara baik dalam pembelajaran mengambar di TKK
Syaloom Ende. Dalam bentuk tabel dapat disajikan sbb:

Tabel 6

Aktivitas Guru Dalam Menerapkan Metode Penugasan

\begin{tabular}{|c|c|c|c|}
\hline No & Siklus & Prosentase & Kriteria \\
\hline 1 & I & $75 \%$ & Baik \\
\hline 2 & II & $90 \%$ & $\begin{array}{c}\text { Sangat } \\
\text { Baik }\end{array}$ \\
\hline
\end{tabular}

Dalam bentuk diagram dapat dilihat di bawah ini.

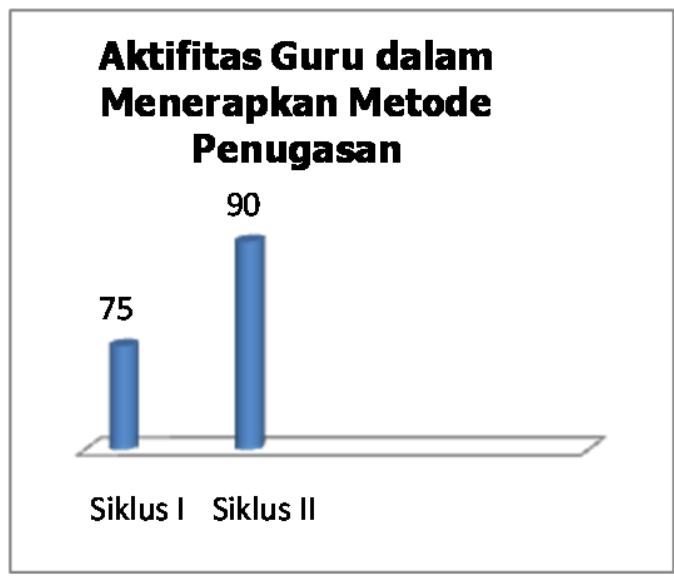

Gambar 6 Diagram Perbandingan aktivitas guru siklus I dan II

\section{Kemampuan Meggambar anak Kelompok B di TKK Syaloom Ende}

Berdasarkan data hasil pengamatan menggmbar anak pada Pra dari 19 anak 6 orang baru berkembang atau $31,57 \%, 10$ anak mulai berkembang atau 52,63\%, Berkembang sesuai harapan 3 orang atau $15,78 \%$. Pada siklus I menunjukan bahwa baru berkembang 0 anak, mulai berkembang 9 anak atau 47.36, berkembang sesuai harapan 8 anak atau $32,10 \%$, dan berkembang sesuai harapan 2 anak atau $10,52 \%$. Pada siklus II terjadi peningkatan dari 19 orang 0 anak 0 baru berkembang, 7 anak mulai berkembang atau 36,84\%, Berkembang sesuai harapan 12 orang atau $63,15 \%$. Dapat dilihat pada tabel 7 berikut ini: 
Tabel 7

Kemampuan menggambar anak Pre tes, Siklus I dan II

\begin{tabular}{|c|c|c|c|c|c|c|}
\hline $\begin{array}{l}\text { Hasil } \\
\text { Mengga } \\
\text { mbar }\end{array}$ & $\begin{array}{l}\text { Prasi } \\
\text { klus }\end{array}$ & $\%$ & $\begin{array}{l}\text { Sikl } \\
\text { us I }\end{array}$ & $\%$ & $\begin{array}{l}\text { Sikl } \\
\text { us } \\
\text { II }\end{array}$ & $\%$ \\
\hline BB & 6 & $\begin{array}{l}31, \\
57\end{array}$ & 0 & 0 & 0 & 0 \\
\hline MB & 10 & $\begin{array}{l}52, \\
63\end{array}$ & 9 & $\begin{array}{l}47, \\
36 \\
\end{array}$ & 7 & $\begin{array}{l}36, \\
82\end{array}$ \\
\hline BSH & 3 & $\begin{array}{l}15, \\
78\end{array}$ & 8 & $\begin{array}{c}42, \\
10\end{array}$ & 12 & $\begin{array}{l}63, \\
15\end{array}$ \\
\hline BSB & 0 & 0 & 2 & $\begin{array}{l}10, \\
52\end{array}$ & 0 & 0 \\
\hline Jumlah & 19 & & 19 & & 19 & \\
\hline
\end{tabular}

Berdasarkan tabel di atas dapat dilihat pada diagram dibawah ini.

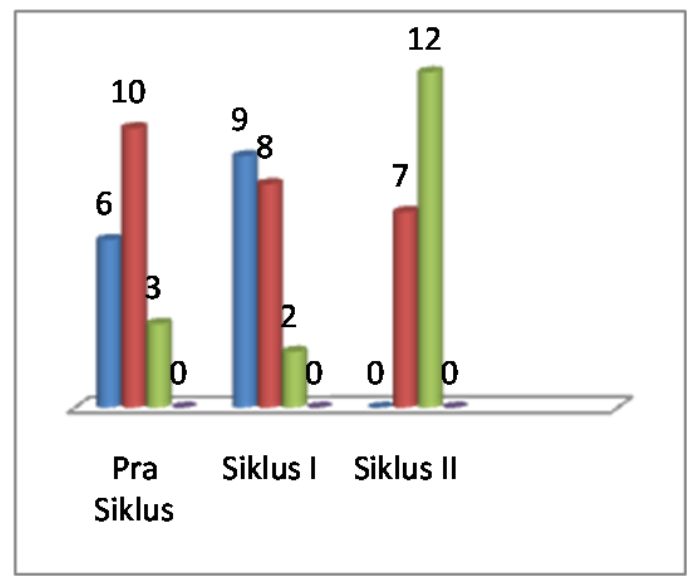

Gambar 7. Diagram perbandingan kemampuan menggambar Pra Siklus, Siklus I dan Siklus II.

\section{SIMPULAN DAN SARAN}

Hasil penelitian menunjukan bahwa; (1) Metode pembelajaran penugasan sudah diterapkan dengan baik dalam pembelajaran menggambar pada anak kelompok B di TTK Syaloom Ende. Hasil observasi membuktikan bahwa pada siklus I tingkat penerapan adalah 75\% dengan kategori baik dan pada siklus II meningkat menjadi sangat baik dengan persentase $90 \%,(2)$

Kemampuan menggambar anak meningkat setelah diterapkan metode penugasan pada anak kelompok B di TKK Syaloom. Hal ini dapat dilihat dari hasil observasi pada Pra siklus, untuk anak yang baru berkembang (BB) adalah 6 orang anak, anak yang mulai berkembang (MB) adalah 10 orang anak, anak berkembang sesuai harapan (BSH) adalah 3 orang anak dan untuk anak bertumbuh sangat baik (BSB) 0 anak. Pada siklus I dari 19 orang anak baru berkembang 0 orang, mulai berkembang 9 orang, berkembang sesuai harapan adalah 8 orang anak dan bertumbuh sangat baik adalah 2 orang anak. Pada siklus II meningkat dari 19 anak yang baru berkembang 0 orang, mulai berkembang 0 orang, bertumbuh sangat baik adalah 7 orang anak, dan untuk yang berkembang sesuai harapan berjumlah 12 orang. Berdasarkan hasil tersebut dapat disimpulkan bahwa penggunaan metode penugasan dapat meningkatkan kemampuan menggambar.

\section{DAFTAR PUSTAKA}

Arikunto

(2013).PenelitianTindakanKelas Jakarta PT Gresindo

Dalyono (2012). Psikologi Pendidikan. Jakarta Rinekacipta

Dadang Yudistira 2013.Penelitian Tindakan Kelas. Jakarta PT Gresindo

Depdiknas, (2008) Pendidikan dan Latihan Profesi Guru, UNJ, Jakarta

Dinn Wahyudin dkk,(1995), Pengantar Pendidikan, Universitas Terbuka, Jakarta

Sudirman, dkk, (1984), Ilmu Pendidikan, PN. Rosda Karya, Bandung

Slavin, Robert E. (2009). Cooperative Learning: Teori, Riset, dan Praktik.Penerjemah: Lita. Bandung: Nusa Media.

Sardiman, A,M. 1990. Interaksi dan Motivasi Belajar Mengajar. Jakarta: Rajawali.

Koenjaraningkat, 2003 Metodologi Penelitian Kualitatif . PN. Rosda Karya, Bandung

Udin S Winataputra dkk, (1991), Teori dan Pembalajaran, Universitas Terbuka, Jakarta 